\title{
SUGGESTIONS AS TO THE DESCRIPTION AND NAMING OF SEDIMENTARY ROCKS
}

A. J. TIEJE

University of Colorado

It seems unnecessary to apologize for suggestions as to describing and naming sedimentary rocks. ${ }^{x}$ Shaw has recently said:

The need of carefully recorded descriptions of the physical characteristics of ancient sediments is especially worthy of emphasis. . . . . Notwithstanding the fact that advances have been made, there is as yet no adequate systematic classification that is generally acceptable. There is not even a satisfactory nomenclature.

To attempt a thoroughgoing logical classification of sedimentary rocks is beyond the scope of this article. Unless Grabau's compounding of prefixes into one dinosaurian term is deemed objectionable, his classification can scarcely be bettered. Here only two lines of suggestion are offered. One aims at systematizing field descriptions of rocks. The other deals with problems of nomenclature which chiefly arose during the writer's examination of three hundred specimens and eighty thin sections of the so-called "Deadwood" formation in the Bighorn Mountains, Wyoming.

FIELD DESCRIPTION OF SEDIMENTARY ROCKS

Lahee, in a warning against the padding of rock descriptions, remarks that every detail not germane to the immediate purpose of a given report should be omitted. ${ }^{2}$ Were reports used only by persons interested in such immediate purposes, the comment would hold good. But if one tries to discuss the conditions of sedimentation in any given region, he is either forced to personal reconnoissance of adjacent regions or to dependence upon published reports of those regions. For such purposes the average descriptions of sediments are lamentably inadequate. Accordingly, there is here

This article was written in April, 1920.

2 F. H. Lahee, Field Geology, p. 450 . 
advocated a list of points in the description of sedimentary rocks which, it is believed, should never be omitted.

The list is as follows:

I. Location.-Nothing is more provocative of time-wasting than for a second observer to search for a vertical section made "on Wolf or Cow Creek," said creek being in a narrow canyon, 15 miles long. Various more accurate modes of statement readily suggest themselves.

2. Name of rock.-This, a matter determinable partly in the field, partly in the laboratory, is later discussed.

3. Massiveness or stratification.--This should include mention of the average thickness of beds; or, if there are alternations, reference to average thickness for each type.

4. Color, fresh and weathered.-Names for color naturally involve a personal equation. Simplicity is often needed. Admirable as are the descriptions of sediments in such a professional paper as No. 78, the amount of space devoted to refinements of color might well have been allotted to other details. Too often the color of pebbles in a conglomerate is not considered apart from the color of the matrix; secondary color, whether of pebbles or cement, is not distinguished from primary, etc.

5. Hardness. - The employment of a mathematical scale, as with minerals, seems impossible. Hardness, however, is usually a result of cementation. The following terms are perhaps usable: (a) soft: rock easily broken between the fingers; (b) subhard: rock breakable by a light hammer tap; $(c)$ hard: rock broken only by a sharp hammer blow; $(d)$ superhard: rock dense and resistant to the hammer. Doubtless, strength of arm is here a factor; but the personal equation is less than with color.

6. Size of grain.-In the field, measurements can rarely be made. Accordingly, exact limits for such terms as fine-grained, medium-grained, coarse-grained are not advocated. However, the term "pebble" should denote only material over a given size, say $\frac{1}{4}$ in. in diameter. The most inexpert assistant knows such terms as oölitic, pisolitic, etc.

7. Mineral composition.-In the field, statement of mineral composition is seldom more than a guess. The use of proper 
qualifying adjectives, however, and attention to the order of their arrangement, would be valuable. Arenaceous glauconitic limestone should not be used when glauconitic arenaceous limestone is meant.

8. Luster.-Only occasionally does one find such remarks as "vitreous sediments," "clayey surface," etc. Perhaps luster has no great significance. Yet might not freshly exposed rocks be said to have vitreous, subvitreous, dull, earthy, etc., luster?

9. Lateral variation.-The importance of this factor can hardly be overemphasized. Any complete description of the "Fountain conglomerate" of the Front Range, e.g., would at once raise doubt as to the ordinary explanation of its origin.

It will be at once remarked that none of these characters throws so much light on the history of a formation as does, say, the mere mention of drying-cracks. ${ }^{\mathrm{I}}$ May that not be because dryingcracks have been studied by a geologic genius? The trouble with our field descriptions is that we incline to note only the unusual. Moreover, the extension of the writer's list to include drying-cracks, ripple marks, jointing, topographic result of erosion, and other matters, would defeat his very practical aim. An elaborate schedule cannot be recalled in all its ramifications. The simple list here advocated can be easily mastered.

THE NAMING OF SEDIMENTARY ROCKS IN GENERAL

As stated, no attempt is made to present a complete classification of sedimentary rocks. It seems possible, however, to group all sedimentary rocks as follows, partly by the aid of field observations, partly by microscopic examination:

A. Organic-

I. Calcareous rocks

2. Ferruginous rocks

3. Siliceous rocks

4. Carbonaceous rocks

5. Rarer types

I There is a further educational value in detailed, systematic description. In courses in advanced general geology, students are often required to make vertical sections based on folios, etc., and even to describe formations in class. If descriptions are so meager that students cannot visualize the sections they describe or construct, is not the value of such work greatly vitiated? 
B. INORGANIC-

I. Of chemical origin

a) Calcareous rocks

b) Ferruginous rocks

c) Siliceous rocks

d) Halides

e) Sulphates

f) Rarer types

2. Of mechanical origin

a) Uncemented

b) Cemented

It is highly doubtful whether new names under all these headings are needed. Whoever is not enamored of the emptiness of Hegelian dichotomy and its dread of intercrossing rubrics will rest satisfied with the use under $\mathrm{A}$ of such stand-bys as bacterial limonite (A 2), diatomaceous earth ( $\mathrm{A}_{3}$ ), or coal ( $\mathrm{A}_{4}$ ). Like granite, diorite, gabbro, these names mean something to the geologist who cannot be forever searching his Greek or Latin lexicon for prefixes and suffixes. Nor can any inventor of systems hope to force aside such terms as travertine ( $\mathrm{B} \mathrm{r} a$ ), clay ironstone $(\mathrm{B} \mathrm{r} b)$, novaculite (B $\mathrm{I} c)$, salt (B $\mathrm{I} d)$, gypsum (B $\mathrm{I} e$ ).

THE NAMING OF ROCKS UNDER A I AND B 2

Obviously, if such familiar names as onyx, sinter, uintaite gypsum are not readily replaceable, there must be a deeper reason even than their establishment in usage. The analysis of this reason results, it is believed, in the discovery that, preponderantly, such names have three great values: (I) they are simple; (2) they aid clear visualization; (3) they suggest a dominant mode of origin. Dissatisfaction with such terms as limestone and sandstone probably arises, it may be unconsciously, from the failure of these names to meet the two latter criteria.

Does not, then, the renaming of organic calcareous rocks and of "clastics" involve, as its pivotal motive, the use of a terminology which shall at least approach the suggestiveness of "coal," "tripoli," etc.? Furthermore, should not the new names be simple or at least readily comprehensible? Should they not aid visualization? And should they not somehow unveil the complex of conditions under which a given rock originated? 
In pursuance of this belief, the renaming of rocks falling under $\mathrm{A} \mathrm{I}$ and $\mathrm{B} 2$ is considered from five points of view: (I) rock source of the sediment; (2) size and shape of grain; (3) degree of cementation; (4) mineral composition; (5) fossil content.

r. Rock source.-Seemingly, there is much satisfaction in speaking of aqueous and eolian sediments, perhaps even more in mentioning an anemopotamoclast. Nevertheless, such terms do not aid the sedimentary-rock student in the same way that peridotite or bostonite aids the igneous-rock student. True, one cannot assert that sands from gabbro rock sources will look different from sands from granite rock sources; of the requisite thin sections there are too few descriptions to tell. In the writer's own experience, nevertheless, Cambrian sands derived from the microcline granites of Wyoming do seem to have a characteristic appearance under the microscope. Would it not secure definiteness of description if sedimentary rocks, mainly, of course, sandstones, had prefixed to their colorless names such terms as granitogene, gabbrogene, quartzitogene?

2. Size and shape of grain.-Shape of grain should be an essential part of a microscopic description. The terms angular, nearangular, subrounded, rounded might constitute a useful series.

Size of grain is, under the microscope, capable of exact delimitation. The scale used in connection with igneous rocks is not, however, subdivided enough. Accordingly, the adoption of a modification of the New York City Aqueduct standard is advocated. The terms suggested chiefly, perhaps, apply to sandstones, somewhat to limestones, little to shales.

Sedimentary rock very coarse-grained............. Sedimentary rock coarse-grained.......... grains between 0.5 and I mm. Sedimentary rock medium-grained ........ grains between 0.25 and $0.5 \mathrm{~mm}$. Sedimentary rock fine-grained........... grains between 0.1 and $0.25 \mathrm{~mm}$. Sedimentary rock very fine-grained........ grains between 0.05 and $0.1 \mathrm{~mm}$. Sedimentary rock superfine-grained............ grains below $0.05 \mathrm{~mm}$.

By this scale, of course, arkoses, graywackes, conglomerates, breccias, even most grits would be very coarse-grained. It will be observed, however, that the terms in the table refer to measurements under the microscope and for sandstones, limestones, and 
shales only. For field use in connection with arkose, graywacke, conglomerate, breccia, and grit, other sizings for fine-grained, medium-grained, coarse-grained are advocated.

Fine-grained arkose (graywacke, etc.) .........grains to $\frac{1}{8}$ in. in diameter Medium-grained arkose (graywacke, etc.).... grains from $\frac{1}{8}$ to $\frac{1}{4}$ in. in diameter Coarse-grained arkose (graywacke, etc.)....... grains over $\frac{1}{4}$ in. in diameter

In most cases, particularly in conglomerates, maximum and minimum as well as average sizes should be noted.

Some term seems needed to denote a rock which is mainly an even-sized matrix, but contains a few pebbles over $\frac{1}{4}$ in. in diameter. Pebbled sandstone, pebbled limestone, pebbled shale are advanced.

3. Degree of cementation.-The microscope permits the abandonment of the field terms to denote hardness: soft, subsoft, hard, superhard. The following incomplete table is tentatively offered for criticism.

\section{Rock Not Well Cemented \\ (Primarily field terms)}

Sandrock

Limerock

Magnesian limerock

Clay

Arkose

Glauconite sandrock

Ferrite sandrock

Gravel
Cemented; Grains Not Interlocked

Sandstone to quartzite sandstone

Limestone

Dolomite

Shale

Arkosite to quartzite arkose

Glauconitite (existent?)

Ferrite

Conglomerate
Cemented; Grains Interlocked

Orthoquartzite

\{Paraquartzite

Orthomarble

Paramarble

SOrthodolomite

Paradolomite

Slate

Arkositite

Existent?

Existent?

Quartzite-

conglomerate

Most of these terms are comprehensible at a glance. By orthoquartzite is meant rock cemented only through infiltration and pressure. By paraquartzite is meant quartzite mainly originating through contact metamorphism.

Doubtless it is illogical to remove quartzite, marble, and slate from the category of metamorphic rocks. However, quartzites, slates, and marbles are universally given a place in vertical sections and in geologic folios are described under sediments. Schists and gneisses are not so treated. Practical exigencies would seem to override Aristotelian "laws." 
4. Mineral composition.-In the field, proportions between minerals cannot be determined. Under the microscope they can. The only true problems which arise concern the existence in given rocks of varying proportions of quartz and feldspar, of quartz and calcite, of quartz and glauconite, of calcite and siderite, of calcite and glauconite, of siderite and glauconite, or of various analogous but rarer combinations. At present, arenaceous limestone is used to denote a rock preponderantly calcareous and, may we say, onefourth arenaceous. Calcareous sandstone is employed when such percentages are reversed. But in the writer's experience a number of rocks exhibit percentages of minerals close to $50: 50$. It is suggested that such terms as calarenite, sidarenite, glaucarenite would prove useful and not uneuphonious names for 50:50 combinations of calcite and quartz, siderite and quartz, glauconite and quartz. Limestone-glauconite, limestone-ferrite are examples of similarly compounded names for other mineral mixtures in rocks. Simple field names suggested on page 655 would thus be used only in emergencies.

The presence of glauconite involves a minor problem. Except when calcite is a cement, its presence in small percentage in a sandstone would hardly warrant the use of the name calcareous sandstone. Glauconite, however, throws some light upon the conditions of deposition. It is advocated that glauconitic as an adjective be employed even if the percentage in a sandstone or limestone be as low as 5 per cent.

5. Fossil content.-Fossiliferous sandstone, shale, and limestone are names already familiar. However, every geologist should recognize at sight the various invertebrate phyla and the main classes. And many geologists could thus characterize fossilbearing rocks as predominantly graptolitic, coralline, vermicosic, pelmatozoic, bryozoan, brachiopodic, molluscan, trilobitic, etc. Coquina seems to be a term for pelecypodic limerock.

\section{ILLUSTRATIVE DESCRIPTIONS OF SEDIMENTS}

With some hesitation, the present discussion is closed with illustrative descriptions of hand specimens of Cambrian rocks and 
of thin sections made therefrom. Each description, though brief, includes (I) locality, position in stratigraphic column, and description of field specimen; (2) texture, list of constituents, and relative proportion of more important minerals; (3) description of the chief mineral or minerals; (4) brief description of minor minerals; (5) name. Items (I), (2), (3), (5) are never omitted, and here each is given a separate paragraph; (4) is sometimes omitted. Terms logically connected are hyphenated, as finegrained; glauconite-limestone; ferruginous-calcareous.

The descriptions are, as stated, purely illustrative. It may be added, however, that the writer has ventured partly to base upon these and other thin sections certain conclusions upon Middle Cambrian paleogeography rather at variance with the accepted account for Wyoming.

Wy 16: Taken in unnamed creek on south side of Duncom Mountain, $\frac{1}{8}$ mile east of Devil Canyon Road, $20 \mathrm{ft}$. above granite.

Description of hand specimen: Arkose, massive, gray-yellow to buff, weathering brownish-white to gray, with grayish-pink irregular lenses, cross-bedded; pebbles quartz and feldspar, usually about $\frac{1}{4}$ in., in finer but arkosic matrix; quartz angular to subrounded, iron-stained; feldspars pink angular cleavage fragments; traces of basic material?

Texture granular-fragmental. Constituents quartz, 80 per cent; microcline and a plagioclase near oligoclase, I5 per cent; small amounts of orthoclase, biotite, ilmenite, zircon, apatite, as accessories, and kaolin, sericite, leucoxene, muscovite, limonite as alteration products. Liquid and gas inclusions in quartz. Cement quartz and limonite.

Two marked groups of quartz grains. Larger average 0.4 to $0.5 \mathrm{~mm}$. in diameter, smaller 0.06 to $0.08 \mathrm{~mm}$. Larger grains subrounded to oval, smaller angular. Vein quartz suggested by wavy extinction.

Microcline fragments quadrangular, fresh; plagioclase same. Either rarely over $0.08 \mathrm{~mm}$. Muscovite apparently not primary.

Classed: granitogene fine-grained arkose. 
Wy 23: Taken at Middle Fork of Crazy Woman Creek, ${ }^{\mathrm{r}}$ I $5 \mathrm{ft}$. above granite.

Description of hand specimen: Arkose, quartzitic, red-brown, massive, coarse, interbedded with finer-grained non-arkosic sandstones. Quartz grains rounded, uniform-sized, up to $\frac{1}{8}$ in. in diameter. Feldspars fresh cleavage fragments, about 33 per cent of rock, up to $\frac{1}{8}$ in. in diameter. General vitreous luster.

Texture granular-fragmental, secondary growth of quartz grains. Constituents quartz, 95 per cent; small amounts of biotite, limonite, apatite, zircon (?). Cement quartz and limonite.

One quartz fragment $3 \mathrm{~mm}$., largest otherwise $0.15 \mathrm{~mm}$.; $5^{\circ}$ per cent of quartz 0.8 to I mm.; rounded and oval.

Classed: granitogene fine-grained arkosite.

Wy 27: Taken at Johnson Creek, $4 \mathrm{ft}$. above granite.

Description of hand specimen: Sandstone, massive, buff, with $\frac{1}{16}$ in. bands of chocolate-brown, doubtless iron stain along obscure bedding planes; contains rare pebbles of purplish shale and yellowish quartz, minimum $\frac{1}{8}$ in., maximum $\mathrm{I}$ in. In general medium-grained, friable, subvitreous luster.

Texture granular-fragmental. Constituents quartz, 6o to 80 per cent, dependent on amount of feldspar, now altered to sericite; small amounts of microcline, biotite, hornblende, plagioclase near oligoclase, zircon, apatite, magnetite, ilmenite (inclusion) as accessories, and kaolin and sericite as alteration products. Liquid and gas inclusions in quartz. Cement limonite, kaolin, sericite, possibly chalcedony.

Quartz vari-sized, largest grain 0.55 by $0.25 \mathrm{~mm}$., no grains below $0.05 \mathrm{~mm}$; near-angular to subrounded, frequently oval. Feldspars suggest secondary growth, averaging 0.05 to $0.08 \mathrm{~mm}$.

Classed: medium-grained pebbled sandstone.

Wy 50: Taken $\frac{1}{4} \mathrm{mi}$. from mouth of tributary, flowing westward from Hunt Mountain to South Beaver Creek, in float not far above granite; similar material in place, $30 \mathrm{ft}$. south and $\mathrm{to} \mathrm{ft}$. above granite.

I The belt of exposure is so narrow that this locality seems sufficiently identified. 
Description of hand specimen: Arkose conglomerate, pebbles not ranging above $\frac{3}{8}$ in. Prevailing color where fresh dark-brown shot with gray, the pink of feldspar sharply contrasting; from dirty grays and whites of weathered surface pebbles stand out in relief. Fucoid markings on what may be bedding-planes $\mathrm{I}$ in. apart. Pebbles 90 per cent quart $z$, faintly brownish-green, rounded to near-angular, breaking with matrix; feldspars pink fresh cleavage fragments. Matrix 90 per cent of rock, sand, fine-grained, dull to earthy luster.

Texture granular-fragmental, large grains showing micrographic intergrowth. Constituents quartz 90 per cent; microcline, orthoclase, uncertain plagioclase 8 per cent; small amounts of biotite, apatite, zircon as accessories, and sericite, kaolin, limonite, and chlorite as alteration products. Liquid and gas inclusions in quartz. Cement a sericitic-kaolinic-limonitic "mess."

Quartz vari-sized, 1.5 by $0.8 \mathrm{~mm}$. in larger grains, perhaps vein quartz, to judge by wavy extinction; average grains, $0.08 \mathrm{~mm}$.; rounded to near-angular. Microcline fresh, 0.03 to $0.04 \mathrm{~mm}$. Orthoclase same size, largely sericitized. Much organic material, seemingly chitinous.

Classed: ferruginous arkose-conglomerate.

Wy 93: Taken on Willow Creek at Burgess Ranger Station, $2 \mathrm{ft}$. above granite.

Description of hand specimen: Shale, thin-bedded, green when fresh, sparsely specked with glistening mica flakes and containing lenses of whitish-green sandstone, I in. long; on weathered surface bluish-black. Hard, arenaceous, fracturing irregularly, fresh surface of dull luster, bedding-planes subvitreous luster and slightly wavy.

Texture granular-fragmental, pilitic through alteration and with parallel arrangement of minerals, excluding quartz. Constituents chlorite, sericite, epidote, presumably alterations from biotite, muscovite, feldspar; small amounts of quartz, plagioclase, magnetite, zircon. Glauconite indeterminable. Cement a sericiticchloritic felt. 
Quartz rarely $0.06 \mathrm{~mm}$., very angular. Plagioclase rare. Biotite bleached.

Classed: micaceous-arenaceous shale.

Wy 2: Same locality as $W y \mathrm{I} 6,40 \mathrm{ft}$. above granite.

Description of hand specimen: Sandstone, thin-bedded, alternating and interleaved with fissile green shales; now banded green and white, subsoft, micaceous, now reddish-green, medium-grained, calcareous.

Texture granular-fragmental. Constituents quartz $9 \circ$ per cent; glauconite 8 per cent; magnetite, ilmenite, calcite as accessories, limonite and leucoxene as alteration products. Cement calcite.

Quartz averages $0.05 \mathrm{~mm}$., angular; rare vein quartz. Glauconite in aggregates $(0.16 \mathrm{~mm}$. diameter) oval to rounded, bordered and veined by limonite; no seeming relation to shell fragments.

Classed: glauconitic superfine-grained sandstone.

Wy 9: Same locality as $W y \mathrm{I} 6, \mathrm{r} 70 \mathrm{ft}$. above granite.

Descripton of hand specimen: Glauconite sand, massive, emerald green, crumbling, coarse-grained, subvitreous luster.

Texture granular-fragmental. Constituents glauconite 95 per cent; limonite as alteration product 5 per cent. Cement limonite. Various chitinous fragments and rods.

Glauconite aggregates as in $W y$ 2, but fresher.

Classed: glauconite sandrock.

Wy 25: Same locality as $W y 27$, approximately $30 \mathrm{ft}$. above granite.

Description of hand specimen: Sandstone, massive, buff where fresh, weathering dark-red. Superhard, fine-grained, dull luster. Weathering exhibits buff nodules in relief.

Texture granular-fragmental. Constituents quartz 85 per cent; small amounts of biotite, muscovite, glauconite, magnetite, ilmenite, plagioclase, microcline, zircon, apatite as accessories, and leucoxene, kaolin, limonite, sericite, chlorite, epidote as alteration products. Liquid and gas inclusions in quartz. Cement quartz and limonite.

Quartz averages $0.2 \mathrm{~mm}$., angular; fragments often elongate; one grain 0.6 by $0.35 \mathrm{~mm}$; vein quartz rare. Plagioclase a mass 
of sericite needles, microcline much fresher; average size for both, $0.05 \mathrm{~mm}$. Biotite shredded. Muscovite largely secondary, but some long twisted primary fibers.

Classed: granitogene glauconitic-ferruginous fine-grained sandstone.

Wy 58: Taken at Turkey Creek, $\frac{1}{4} \mathrm{mi}$. south of Steamboat Point, $9 \mathrm{ft}$. above granite.

Description of hand specimen: Limestone, I-in. lenses, reddishbrown, coarse-grained; occurring in shale, fissile, paper-thin, green with silky luster, trilobitic on bedding-planes (Ptychoparia), brachiopods rare.

Texture granular-fragmental. Constituents calcite 95 per cent; small amounts of quartz, magnetite, zircon, siderite as accessories. Cement calcite and a trifle limonite.

Calcite averages $0.75 \mathrm{~mm}$.; often in rods and rectangular blocks, obviously fossil fragments, the remaining calcite due to solution and redeposition. Within shell fragments a finely comminuted mixture of quartz, calcite, siderite; limonite, probably from siderite, outlines fragment edges. Quartz 0.02 to $0.03 \mathrm{~mm}$., angular.

Classed: coarse-grained brachiopodic limestone.

Wy 99: Taken at Deer Creek, I mi. northwest of Sheep Mountain, roo ft. below the persistent sandstone described as $W y 89$.

Description of hand specimen: Limestone, massive I-in. bed between thick green shales; gray-blue, weathers dirty-brown, crossed by veins of calcite; hard, medium-grained, subvitreous luster, brachiopodic and trilobitic.

Texture granular-fragmental. Constituents calcite $9 \circ$ per cent; small amounts of quartz, magnetite, glauconite, pyrite, zircon, ilmenite as accessories, and leucoxene as alteration product.

Calcite $0.35 \mathrm{~mm}$., anhedral; at times within shell fragments and then comminuted; "rods" clearly from genal spines of trilobites, fragments 4 to $5 \mathrm{~mm}$. long. Quartz mainly in shells, angular, seldom as much as $0.04 \mathrm{~mm}$. Glauconite seemingly developed in shells. Much chitinous material.

Classed: medium-grained brachiopodic trilobitic glauconitic limestone. 
Wy 105: Taken at Horse Creek No. 3, I mi. west of Sheep Mountain, I25 ft. above granite and at much the same horizon as Wy 99 .

Description of hand specimen: Limestone, massive, light-green and specked with hard black grains, weathering dirty brown-red. Hard, fine-grained, subvitreous luster, fractures conchoidally.

Texture granular-fragmental. Constituents calcite 60 per cent; glauconite 30 per cent; quartz Io per cent. Magnetite and zircon as accessories, and limonite as alteration product.

Calcite $0.15 \mathrm{~mm}$., probably due to recrystallization.

Calcite in shell fragments as in $W y 99$. Quartz grains surprisingly large, average $0.1 \mathrm{~mm}$. and up to $0.5 \mathrm{~mm}$.; very angular. Glauconite in large aggregates, even 2 by $8 \mathrm{~mm}$.; some curved, as if by replacement of whole fossils; indifferently near to or remote from magnetite; fresh. Limonite mainly from magnetite.

Classed: fine-grained brachiopodic trilobitic glauconitelimestone.

Wy 89: Taken from massive bench on south side of Bald Mountain.

Description of hand specimen: Sandstone, massive, pinkish buff, slightly splotched with brown, weathering dull grayish-white; subsoft, fine- to medium-grained, traces of shale streaks, earthy to subvitreous luster, brown splotches interpreted as oxidation of trilobite shields. Cross-bedded? Most persistent bed in the Cambrian below the flat pebble.

Texture granular-fragmented. Constituents quartz 95 per cent; small amounts of biotite, magnetite, ilmenite, plagioclase, glauconite as accessories, and leucoxene and limonite as alteration products. Cement quartz and calcite.

Quartz averages $0.15 \mathrm{~mm}$; largest grain 0.3 by $0.15 \mathrm{~mm}$.; angular, sufficiently cemented to suggest quartzite; few indications of secondary growth. Grains limonite-rimmed. Biotite much shredded. Chitinous rods.

Classed: fine-grained quartzite-sandstone.

$W y 6_{3}:$ Same locality as $W y 58$, I $50 \mathrm{ft}$. above granite.

Description of hand specimen: Limestone, massive, gray-green, weathering reddish-brown to gray. Subsoft, medium-grained, argillaceous, arenaceous, glauconitic, ferruginous. 
Texture granular-fragmental. Constituents calcite $5 \circ$ per cent; quartz $33 \frac{1}{3}$ per cent; siderite Io per cent; small amounts of magnetite, ilmenite, zircon, muscovite, glauconite as accessories, and limonite as alteration product.

Calcite $0.2 \mathrm{~mm}$., giving evidence of recrystallization; also as rods. Glauconite aggregates about $0.5 \mathrm{~mm}$., much replaced by limonite. Limonite also edges siderite rhombs. Quartz $0.04 \mathrm{~mm}$., near-angular to subrounded.

Classed: arenaceous trilobitic medium-grained glauconitelimestone.

Wy I3: Same locality as $W y$ I6, $260 \mathrm{ft}$. above granite.

Description of hand specimen: Limestone, thin-bedded, bluegray, subsoft but brittle, the I-in. layers separated by micaceous shale; subvitreous luster, black-specked, seemingly unfossiliferous.

Texture granular-fragmental. Constituents calcite $5 \circ$ per cent; quartz 25 per cent; glauconite 20 per cent; small amounts of ilmenite, zircon, apatite as accessories. Liquid and gas inclusions in quartz. Cement calcite.

Quartz 0.I mm., angular. Calcite grains $0.5 \mathrm{~mm}$.; main occurrence as rods.

Classed: arenaceous trilobitic medium-grained glauconitelimestone.

Wy 87: Same locality as $W y 89,4 \mathrm{ft}$. above that horizon.

Description of hand specimen: Sandstone, massive, gray-green with irregular-bedded effect due to light-colored stretches between dark-brown bands, with parallel orientation of Dicellomus shells; soft, coarse-grained, calcareous, particularly toward top, glauconitic, dull to subvitreous luster. Cross-bedded.

Texture granular-fragmental. Constituents quartz 80 per cent; glauconite ro per cent; calcite 5 per cent; small amounts of biotite, muscovite (?), apatite as accessories. Cement calcite. Liquid and gas inclusions in quartz.

Quartz 0.2 to $0.5 \mathrm{~mm}$., subrounded to oval, at times subhexagonal. Glauconite seldom related to shell interiors, not even in an admirable cross-section with quartz fragments in shell and cemented by calcite and limonite.

Classed: glauconitic medium-grained sandstone. 
Wy 84: Taken at Cambrian Creek, tributary to East Fork of Little Bighorn River, long. $10^{\circ} 45^{\prime}$ W., lat. $44^{\circ} 50^{\prime} \mathrm{N}$., $34 \mathrm{ft}$. below the flat-pebble conglomerate.

Description of hand specimen: Limestone, massive, gray-green, weathering gray to reddish brown, subsoft, coarse-grained, arenaceous, glauconitic, subvitreous luster, with calcite veins and I-in. crystals; breaks in smooth angular blocks; presents corrugated surface where calcite has dissolved on weathering.

Texture granular-fragmental. Constituents quartz 47 per cent; calcite 47 per cent; small amount of glauconite as accessory, and limonite as alteration product. Cement calcite.

Quartz averaging $0.3 \mathrm{~mm}$., largest grain 0.5 by $1.8 \mathrm{~mm}$.; subrounded; grains broken and healed by calcite; slight traces of secondary growth; small grains seemingly fragments of larger ones cemented. Calcite shows recrystallization. Glauconite aggregates about o.I mm., rounded. Bryozoan-like fragments.

Classed: glauconitic trilobitic medium-grained calarenite.

Wy 66: Taken on south side Tongue River, directly opposite mouth of Sheep Creek, 6o ft. below the Cambrian-Ordovician contact.

Description of hand specimen: Limestone, $\frac{1}{16}$ - to I-in. beds, greenish-white to buff, hard, fine-grained, argillaceous, arenaceous, subvitreous luster, slightly ripple-marked, raindrop-pitted (?).

Texture granular-fragmental. Constituents siderite 30 per cent; calcite 30 per cent; quartz 30 per cent; glauconite 5 per cent; a little apatite, ilmenite, muscovite, magnetite, and plagioclase; muscovite and plagioclase very rare; a little limonite as alteration product.

Calcite averages 0.I mm., larger grains $0.2 \mathrm{~mm}$. Quartz 0.05 mm., near-angular to subrounded; inclusions of hematite scales (?). No fossils.

Classed: glauconitic-arenaceous medium-grained siderocalcite.

Wy 72: Taken on East Fork of Little Bighorn River, 2 mi. northeast of Little Bald Mountain, at base of Ordovician "Bighorn dolomite." 
Description of hand specimen: Limestone, 4- to 6-in. beds, gray-green, weathering light buff with yellow stains, hard, finegrained, slightly dolomitic, argillaceous, dull luster, lower beds much jointed, causing weathering in subquadrate slabs; flat-spired gastropods abundant.

Texture granular-fragmental. Constituents calcite 99 per cent; a little accessory glauconite, limonite as alteration product. Cement calcite.

Calcite grains often recrystallized, largest $0.3 \mathrm{~mm}$. and apparently cavity-filling.

Classed: gastropodic medium-grained limestone; traces of glauconite.

Wy 69: Same locality as $W y$ 2, $2 \mathrm{ft}$. below Cambrian-Ordoviciancontact.

Description of hand specimen: Conglomerate, massive, greenishgray; pebbles limestone, distinguishable with difficulty on weathered surface, greenish, subsoft, fine-grained, glauconitic, flattened, elongated, length $\frac{1}{4}$ in. to 2 in., often loose ochreous earth, lining cavities, when fresh breaking with matrix, and usually aligned in parallel planes, constituting 50 per cent of rock; matrix limestone, greenish, fine-grained, dull luster. (This is the famous flat-pebble conglomerate of Dakota and Wyoming.)

Texture conglomeratic. Constituents calcite 90 per cent; small amounts of glauconite, quartz, pyrite, magnetite as accessories, and hematite and limonite as alteration products. Cement calcite.

Calcite either as pebbles, merely fragmentary in slide, or as interlocked crystals in matrix. Pebbles characterized by calcite, criss-crossed and specked with glauconite (percentage from 25 to $33^{\frac{1}{3}}$ ), and interlocked with quartz grains below o.or mm. diameter. Quartz very rare in matrix. Pyrite altering to hematite and limonite.

Classed: glauconitic flat-pebble limestone-conglomerate.

Wy 24: Same locality as $W y 23,20 \mathrm{ft}$. below CambrianOrdovician contact.

Description of hand specimen: Seemingly sandstone (and so described by one observer), massive, pink, weathering fainter pink. 
Superhard, fine-grained, argillaceous, and seemingly slightly calcareous, subvitreous luster.

Texture granular. Constituents dolomite 90 per cent; quartz 5 per cent; small amounts of magnetite, glauconite, ilmenite as accessories, and limonite as alteration product. Cement dolomite and limonite.

Dolomite in rhombs, inclusions of limonite; averages $0.07 \mathrm{~mm}$. Quartz rarely over $0.02 \mathrm{~mm}$., very angular. Glauconite altering to limonite, latter also between dolomite crystals.

Classed: glauconitic superfine-grained dolomite. 